Therefore, assuming the sizes of the heats of steel made by the respective processes to average I0, 50, I.5 and 6 tons, and each heat to have required one determination of each of the five usually estimated elements, we would have for the year I9I 3 the interesting data in Table II, in which round figures only are used.

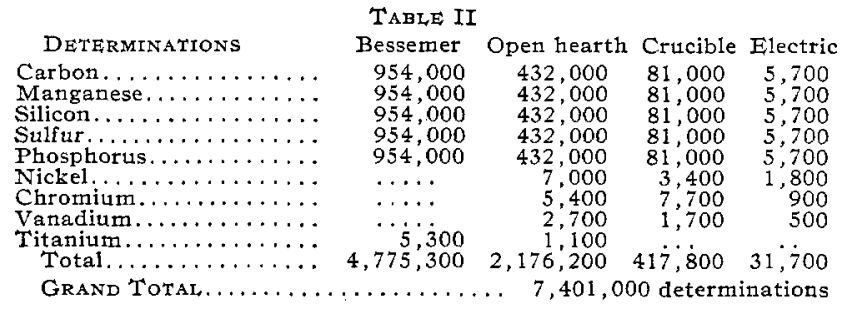

These figures are startling, and yet they do not, by any means, wholly represent the analytical work connected with the production of the steel itself. It is not to be understood that these figures represent the actual conditions, for it is very questionable if one-half the Bessemer steel heats are analyzed; on the other hand, however, many companies make two and three check determinations on a single heat of open hearth steel. The figures as a whole are very probably far short of showing the work of the analytical chemist associated with the production end of the steel industry. The analyses connected with the blast furnace, such as those of pig iron, ores, slag, coal, coke, gases, refractories and water, should be added to these and also those determinations made upon the ordinary or regularly used ferro-alloys and metals, not to mention those necessary for the production of alloy steels containing chromium, nickel, vanadium, titanium, cobalt, tungsten, copper, molybdenum, and perhaps uranium, either singly or in combination.

Frequently much of this steel when it reaches the consumer is again analyzed so that the part analytical chemistry plays in the steel industry is seen to be extensive and absolutely indispensable. Without it we could not ride from New York to Chicago in twenty hours nor drive with safety in an automobile at a fair rate of speed, nor would we have our high structures, huge bridges or viaducts, nor any of the modern mechanical equipment for operating our factories.

To obtain the high fuel efficiency of the blast furnace, the control of the Bessemer converter and of the open hearth furnace has necessitated an extensive and careful study of the weights and volumes of gases, high and low temperature measurements, heats of combustion of gases and fuel. Thus physical chemistry is seen to be an essential aid, since the metallurgy of steel involves principles which are not only chemical but also physical and mechanical. The mositure of the air was of sufficient economic importance to the efficiency of the blast furnace that its removal by refrigeration was undertaken, following a study of the physical chemistry of the blast. In the Talbot open hearth furnace, a bath of molten steel is used to excite the reaction between molten pig iron and iron ore, with a saving of fuel, since the materials themselves burn each other as it were, an achievement following the study of the thermochemical reaction between carbon and oxide of iron.

Not only has inorganic chemistry in its analytical, physical and thermo phases played a highly important part in the steel industry, but also organic chemistry is entering the field. The production of coke is accompanied by the making of coal tar which is the source of benzol and many other valuable bases used throughout the chemical and allied industries. It is now proposed by one of the largest steel producers, to take up this feature and develop it.

In concluding this presentation, which, on account of the broadness of the subject is necessarily very incomplete, mention should be made of the part electricity has more or less recently played. While the process of making steel with electricity is primarily electrothermic, an extensive chemical study of refractories and electrodes was necessary before the process attained its present status. The high temperature which could thus be gotten enabled the use of hitherto impossible combinations for slags with the result that steels of a greater purity became possible and these from scrap or iron containing high percentages of objectionable elements such as phosphorus and sulfur; the chemist was thus also enabled to produce ferroalloys otherwise impossible.

It is hoped that this article may give to those unfamiliar with the metallurgy of iron and steel some idea of the all-important part chemistry has had in the success of one of the greatest of the world's industries.

PitTsBurgh, $P_{A}$.

\section{CONTRIBUTIONS OF THE CHEMIST TO THE IRON AND STEEL INDUSTRY}

By Alierton S. Cusiman

Director Institute of Industrial Research, Washington, D. C.

The contribution of chemistry to the iron and steel industries may be said to have begun with the introduction of the great pneumatic processes of steel making in the latter part of the Igth century. The Bessemer process, brought out in 1863 , and the Siemens-Martin open hearth process which followed soon after, produced a revolution in the iron industry that gave the chemist his first opportunity. Before the days of steel, iron making was largely an empirical art, and no one considered the estimation or control of the impurities which usually accompany the metallurgy of iron to be a matter of vital importance. It was, of course, known through the operation of the puddling and crucible processes that certain elements could be depended upon to confer hardness and toughness, but the very important quantitative rôles in the metallurgy of iron played for good or ill by the ever-present five elements-carbon, manganese, sulfur, phosphorus and silicon-were not understood. It was by means of his original researches into the methods for determining and controlling these so-called impurities that the chemist began to force his coöperation upon the more or less unwilling body of contemporary metallurgists. Even within the metallurgical memory of the present writer, which does not comprise more than a third of a century, iron masters were loathe to recognize the necessity for well-equipped laboratories under the charge of college-bred chemists.

After the ore is mined and shipped, the iron industry begins in the blast-furnace in which chemical reactions involving enormous energy exchanges take place. Just as soon as the professional chemist was allowed to win his way from the laboratory into the works, revolutionary changes in output and economy were very soon accomplished. This move forward constitutes, in the opinion of the writer, the first great contribution to the iron industry made by the chemist.

In the meantime, the steel maker, in charge of the rapidly developing pneumatic processes, required to know and follow the content of carbon, manganese and other impurities during the progress of a heat. Analytical chemistry came to the rescue by devising quick methods of analysis. So rapid has been the development along this line of chemical contribution that the modern metallurgist can literally obtain his information while he waits and thus modify and control the degree and duration of his heats. The writer has information that by a recent method even carbon by combustion can be accurately determined in eight minutes from the time the sample drillings are delivered to the laboratory. The development of modern methods of rapid and accurate analysis may be held to constitute another great contribution of chemistry to the metallurgy of iron and steel.

Modern metallurgy has not been satisfied with the development and improvement of ordinary carbon steels, for modern industrial requirements have demanded the production of alloy steels possessing marvelous and, until very recently, unheard of and undreamt of physical properties. The ores of the rarest elements have been unearthed to produce these wonderful 
alloy steels, and the chemist has been called upon to devise ways and means for their development and study. This evolution bas indeed presented many a knotty problem to the analyst as well as to the chemist in the works. It is no easy chemical task to separate, estimate and control such elements as tungsten, chromium, vanadium, titanium, nickel, cobalt, molybdenum and tantalum as every-day constituents of steel.

Space will permit of only the briefest reference to the very important place that the curious alloys have made for themselves in the metallurgy of iron and steel. The tungsten, chromium, cobalt and molybdenum alloys of varied composition constitute the modern "high speed" steels which have revolutionized machine shop practice. Vanadium and chromiun are used in the manufacture of the so-called anti-fatigue steels for springs and other rapidly moving machine parts. At the New York meeting of the Eighth International Congress of Applied Chemistry, in I9I2, Dr. Carl Duisberg referred to the use of some of these new alloys as follows:

"Of great importance are those alloys of iron with chromium, tungsten and vanadium which possess a high degree of hardness even at $400-500^{\circ} \mathrm{C}$. They are needed by engineers for the construction of steam turbines, for the embossing and spraying of metal objects when heated to redness, a process which has lately found extensive application. Chemists use these kinds of steel wherever chemical reactions are carried out at high temperatures and pressure, as in the synthesis of ammonia according to Haber's process."

According to Dr. Duisberg, the very latest alloy manufactured by Krupp for the manufacture of safety vaults and safes can neither be drilled nor exploded nor can it be cut by the oxyhydrogen flame. In the light of subsequent events we are led to presume that the manufacture of safes was not the only purpose in the minds of our chemist-colleagues across the water. It is interesting to note in passing that unless the chemists of Germany had worked out the synthesis of nitrogen compounds from atmospheric nitrogen as well as the special steels suitable for the construction of the necessary apparatus, the present great world war would have to be brought to an early close.

Another important contribution of chemistry to the iron industry which may be called purely American is along the line of the manufacture of pure iron on the same scale which is usual in steel production. This development, which the writer is in large measure responsible for, has had to win its way against many difficulties and even much prejudice and hostility. Many hundred thousand tons of commercially pure iron are now produced annually in this country and are in demand for many purposes for which iron is more suitable than steel. Pure iron is soft and ductile with a bigh electrical conductivity and useful magnetic properties; for many deep drawing and enamelling purposes it is unequalled, while its slow rusting qualities have given it a wide-spread reputation and use. Some years ago the demand for pure iron could be filled only by the importation of Norway and Swedish charcoal irons; at the present time the industry is fully established in this country on the large scale which our industrial and economic conditions demand. That the chemist has contributed to this line of development there can not be the slightest doubt. It has been found necessary to eliminate the gaseous as well as the solid impurities from these pure irons, and this difficult problem has engaged the closest coöperation between the men in the laboratory and the mill.

In a brief review of this nature it is possible to touch only lightly on the many contributions of chemistry to the iron and steel industry, but the writer's experience is that unless the divisional superintendents in a modern iron and steel plant are themselves chemists as well as metallurgists, they can not be depended upon to carry on progressive work.

INSTITUTE OF INDUSTRIAL. RESEARCH WASHINGTON, D. C.

\section{CONTRIBUTIONS OF THE CHEMIST TO THE ART OF SOAPMAKING}

By Martin Hili, ItTiner

Chief Chemist, Colgate \& Company, New Jersey

Although the art of soapmaking is of long standing it has undergone considerable improvement during recent years. The advance in the science of chemistry has contributed in no small way to the number and magnitude of the successes in this field.

Soapmaking is connected almost inseparably with a number of other related industries among which the chief are the manufacture of alkali, glycerine, edible fats and oils, and perfumery, while the manufactures of candles and lubricants are industries closely associated with soapmaking.

Although many of the larger soap manufacturers make their own caustic soda from soda ash, the manufacture of alkali is a great industry in itself. I would be neglectful, however, if I failed to state here that the manufacture of alkali has advanced so that most of the alkali now on the market is of very high quality and is sold at a very reasonable price.

It was only a comparatively few years ago that the greater portion of the glycerine formed during the process of soapmaking was wasted. It was thrown away with the spent lyes in the process of making "curd" soap, or was left in the soap in the so-called "cold-made" soap. An increased demand for pure glycerine for the manufacture of explosives, confections, and pharmaceuticals has stimulated the soapmaker to recover his glycerine and an article that was once a neglected by-product has now assumed so much importance that no soapmaker could operate with any degree of success without recovering his glycerine, and the profit from the recovery of glycerine is frequently greater than that from the manufacture of soap itself. A knowledge of the physical and chemical properties of glycerine has been utilized in the various processes which have been devised to recover and purify this valuable body. The most important part of these processes is the distillation of the glycerine by means of steam in vacuo. It is not necessary to operate at a temperature sufficiently high to cause any decomposition of glycerine, as was the case in older methods, and improvements in processes employed have worked economics in yield and cost of production. Glycerine of the highest degree of purity is now regularly made on an enormous scale from soap lyes.

During the operation of soapmaking the glycerine is gradually removed from the soap by successive washes. Chemical analysis enables the soapmaker to estimate the total amount of glycerine possibly obtainable in a given operation. Chemical control and a consideration of the cost of operation taken together with the value of glycerine enable him to ascertain the most economical conditions of working.

The process of making "settled" soap, carried on under chemical control, enables the soapmaker to readily produce soap of uniformly high quality.

With an aim to the simplification of the process of soapmaking and the realization of greater economy, new methods of hydrolyzing fats and oils have been devised. In some of these methods, notably those in which sulfo-fatty acids are used, the hydrolysis is effected at atmospheric pressure. Hydrolysis by means of enzymes is also used to some extent. By these processes the larger part of the glycerine is readily recovered and fatty acids suitable for soapmaking are produced. When materials of poor quality are used, as, for instance, cottonseed soapstock, the fat may be hydrolyzed into fatty acids and glycerine, the glycerine recovered, and the dark acids subjected to distillation with steam in vacuo, whereby white fatty acids, suitable for making good quality soap, may be obtained.

A new method of lime saponification gives a lime soap that is brittle and readily pulverizable and which is insoluble even in boiling water. By this method, which requires somewhat 